\title{
Supercritical river terraces generated by hydraulic and geomorphic interactions
}

Edwin R.C. Baynes*, Dimitri Lague, and Jean-Jacques Kermarrec

Univ Rennes, CNRS, Géosciences Rennes - UMR 6118, 35000 Rennes, France

*E-mail address: edwin.baynes@univ-rennes1.fr

\section{ABSTRACT}

The alternating cycle of valley widening through lateral erosion ('strath planation') and valley narrowing through vertical incision into bedrock ('strath terrace abandonment') due to variations in sediment supply $(Q \neg S)$ relative to river transport capacity (Qsc) is a common feature in many mountainous environments, yet our understanding of the mechanics of the processes that drive this landscape change remains poorly quantified. Here, we used an experimental and numerical study to identify the geomorphic and hydraulic controls driving the response of mixed bedrock-alluvial rivers to variable sediment supply, water discharge and tectonic tilting. The experimental channels exhibit a multi-stage response of channel narrowing, stripping of the alluvial cover in a downstream migrating incision wave followed by destabilization of the bed and development of a single vertical step in the bed profile ('knickpoint') when the hydraulic conditions are supercritical. In our experiments headward erosion by knickpoints is the most efficient process of strath terrace abandonment, contributing the majority of the total vertical incision in a short period of time. We show experimentally, that knickpoint developing under supercritical flow conditions, driving the rapid response of fluvial systems to upstream perturbations in Qs/Qsc despite no base-level fall. This has implications for the understanding of distributions of strath terrace ages, the inference of baselevel variations from knickpoint propagation, and how landscapes respond to climatic or tectonic perturbations.

\section{INTRODUCTION}

Past cycles of global climatic change have had consequences for the hydrological regime and the pattern of sediment production and transport within landscapes (Schumm and Parker, 1973; Fuller et al., 2009; Wobus et al., 2010). The balance between the flux of sediment entering a mixed bedrock-alluvial river (Qs) and the capacity of the river to transport that sediment (Qsc) is important in setting the landscape morphology, such as the generation and preservation of flights of strath terraces above the active channel (e.g., Pazzaglia et al., 1998; Wegmann and Pazzaglia, 2002). 
Several mechanisms have been proposed for the generation of strath 'terraces', including climate driven oscillations in Qs/Qsc resulting in valley widening (high Qs/Qsc) or vertical incision (low Qs/Qsc) (Bull, 1990; Hancock and Anderson, 2002). The presence of strath terraces within a fluvial system have also been shown to result from headward incision by 'base-level knickpoints' initiated by fault throw or tectonically driven base level fall (Finnegan, 2013; Finnegan and Balco, 2013), unsteady lateral river erosion (Limaye and Lamb, 2016), bedrock structure (Wohl, 2008), the cutoff and migration of river meander bends (Finnegan and Dietrich, 2011), sea level highstands (Merritts et al., 1994), river capture (Stokes et al., 2002). The influence of tectonics in generating strath terraces is usually limited to the consideration to the initiation of headward migrating incision waves (e.g., Finnegan 2013), while the impact of regional landscape tilting is rarely considered. A clear identification of the mechanism of strath terrace formation is important for the interpretation of the presence and pattern of strath terraces within a landscape to date past climate changes (e.g., Fuller et al., 2009; Stokes et al., 2017), estimate fluvial incision rates (e.g., Lavé and Avouac, 2001), or to help calibrate empirical models of fluvial erosion (Finnegan, 2013). However, a universal model of strath terrace formation is currently limited by an incomplete understanding of the mechanics of vertical and lateral erosion in bedrock and difficulties in identifying the erosional pattern during the response of channel processes to perturbations in Qs/Qsc from preserved strath terrace age distributions.

Here, we present a physical modeling study that explores the mechanisms of channel response and resulting terrace geometry to three scenarios of perturbations to Qs/Qsc. The first two experiments explore the response of a channel following a sudden perturbation to Qs/Qsc from the same initial conditions while the third explores the impact of a gradual decrease in Qs/Qsc, through progressive tilting of the experiment. The experiments identify patterns of erosional response including the resulting preserved terrace morphology, aiding the interpretation of terrace age distributions in natural landscapes for purposes such as the reconstruction of climate or tectonic histories (e.g., Fuller et al., 2009; Stokes et al., 2017)

\section{EXPERIMENTAL SETUP}

Experiments have been used extensively to explore the dynamics of bedrock channels, including abrasion processes (e.g., Johnson and Whipple, 2007), the dynamics of bedrock plucking (e.g., Dubinski and Wohl, 2013), the mechanics of waterfall erosion in homogenous bedrock (e.g., Baynes et al., 2018), and landscape stability (e.g., Hasbargen and Paola, 2000). We used the $80 \mathrm{~cm}$ long, $30 \mathrm{~cm}$ wide and $20 \mathrm{~cm}$ deep Bedrock River Experimental Incision Tank at the Université de Rennes (Fig. 1; S1), with an initial configuration of a thin (2 
$\mathrm{cm}$ ) layer of well-sorted sand (grain size $=250 \mu \mathrm{m}$ ) overlying homogenous silica paste (grain size $=45 \mu \mathrm{m}$ ). The cohesive silica paste material is commonly used to represent bedrock and is eroded by hydraulic shear under clear water flow in the absence of sediment (e.g., Turowski et al., 2005; Turowski et al., 2006; Turowski, 2007) and the experimental channels in this study exhibit a similar hydraulic scaling of width and slope to natural bedrock rivers (Baynes et al., 2018). No direct scaling between our experiments and a particular target natural system is sought but the behavior of the experiment is similar to that observed in natural systems, allowing the dynamics of processes and their controls to be explored quantitatively (Hooke, 1968; SI Section 1).

Constant input water discharge, set within $2 \%$ by a regulated pump on the inflow pipe, was fed into a reservoir upstream of the inlet, and sediment was added using a Gericke infinite screw feeder system. The channel outlet elevation was fixed, although it was free to migrate across the width of the box, and sediment was collected in a reservoir beyond the outlet to avoid deposition in the channel as a result of the outlet. The same initial conditions for the first two experiments were $Q=1.5 \mathrm{l} / \mathrm{min}, \mathrm{Qs}=13.33 \mathrm{~g} / \mathrm{min}$, slope $=4.5^{\circ}$, selected after previous experiments for the best combination of parameters to generate an alluvial river at equilibrium conditions inset in the sand material. Channel slope, width and depth were free to evolve during the course of the experiment through erosion (vertical and lateral) and deposition. After 37 minutes, once the channel had reached a constant width, one parameter was altered while all others kept constant to represent a sudden shift in Qs/Qsc; experiment 1: Qs reduced to $0 \mathrm{~g} / \mathrm{min}$, experiment 2: $Q$ doubled to $3 \mathrm{l} / \mathrm{min}$. In the third experiment, $Q$ s and $Q$ were maintained constant throughout but the slope was increased from an initial slope of $2.5^{\circ}$ at a continuous rate of $1^{\circ}$ per hour for 4.7 hours, gradually decreasing Qs/Qsc. A Leica ScanStation 2 Terrestrial Laser Scanner (green laser footprint $=3 \mathrm{~mm}$ ) was programmed to collect point clouds of the topography every $2 \mathrm{~min}$. The topography was then gridded with a pixel size of $2 \mathrm{~mm}$, and combined with the hydrodynamic model Floodos (Davy et al., 2017), to evaluate the hydraulic conditions within the channel (e.g., Froude number) and to quantify the evolution of the channel geometry (e.g. width and depth) during the experiments (SI Section 2).

\section{EXPERIMENTAL RESULTS AND DISCUSSION}

Changing Qs/Qsc had a significant, rapid and complex impact on the initial stable state (channel width: $150 \mathrm{~mm}$ ) in the first two experiments. Following the removal of input Qs in experiment 1, an initial narrowing of the channel coincided with a downstream migrating incision wave initiated at the inlet that removed the alluvial cover (Fig. 2A), exposing the bedrock surface to erosion. The removal of input $Q s$ led to $Q s / Q s c=0$, providing capacity for 
the flow to entrain and strip the sediment stored in the alluvial bed. Further narrowing of the channel occurred until the bed destabilized into a series of steps (spaced at 25-30 mm with height of 3-5 mm, at $t=83 \mathrm{~min}$ ) in the bedrock surface that evolved into a single vertical step $(15-20 \mathrm{~mm}$ in height at $\mathrm{t}=111 \mathrm{~min})$ that migrated upstream as a knickpoint, depositing material downstream of the plunge pool (Fig. 2A). The same multi-stage process of downstream stripping of alluvial cover followed by knickpoint development and headward erosion also occurred in experiment 2 where $Q$ was doubled (SI Section 3). The development of steps before the generation of a single knickpoint were not observed in the topographic data from experiment 2 as the channel evolved from downstream stripping to headward erosion within the time period between successive laser scans ( $t=120 \mathrm{~s}$; Fig. S5B). Despite this, the knickpoint formed mid-channel in the absence of any base level fall or tectonic uplift.

The initial stages of experiment 3 (until $t \sim 100 \mathrm{~min}$ ) were characterized by an alluvial fan-like regime near the inlet with cone-shaped deposits frequently reworked by high lateral channel mobility (Fig. 2B) while the slope increased (Fig. S5C). As Qs/Qsc decreased, the flow focused into a narrower single thread, triggering the onset of a downstream incision wave of the alluvial cover. Subsequently, a knickpoint developed in the bedrock ( $\mathrm{t}=\sim 208 \mathrm{~min}$ ) which retreated upstream in the same manner as the other experiments (Fig. 2B; SI Section 3). In each experiment, the stripping of alluvial cover by the downstream incision wave coincided with a significant narrowing of the channel inset in the alluvial cover, with the narrowest width occurring in bedrock when a knickpoint had formed (Fig. 2B). The channel narrowing associated with the incision of both the alluvial cover and the bedrock led to the abandonment of the formerly active bed at higher elevations, representing the generation of strath terraces seen in natural environments. However, the rates of vertical incision and terrace abandonment were not spatially or temporally constant during the experiments, with the highest local rates of vertical incision associated with the downstream stripping of sediment and the headward migration of the knickpoints through bedrock (Fig. 2B; SI Section 4). A similar contribution to total vertical incision by knickpoint migration was identified in Hawai'i (Mackey et al., 2014).

The Floodos hydrodynamic model output (SI Section 5; Fig. S10) shows that the sequence of steps, and subsequently the knickpoint, developed in experiment 1 where flow had a Froude number $>1$. The Froude number, a dimensionless number defined as the ratio of the inertia forces to gravitational forces, characterizes the transition from subcritical to supercritical flow when $\mathrm{Fr}>1$. During supercritical flow, interactions between the flow and the bed are inherently unstable (Yokokwa et al., 2013; Izumi et al., 2017; Scheingross and Lamb, 2017), and the development of steps in the bedrock surface occur during our experiments when the 
flow conditions exceed the threshold Froude number for supercritical flow. We therefore refer to these features as 'supercritical knickpoints' to distinguish them from 'base-level knickpoints'. Subsequently, we refer to the terraces generated by the passage of supercritical knickpoints as 'supercritical terraces'.

\section{IMPLICATIONS FOR THE UNDERSTANDING OF NATURAL LANDSCAPES}

Our experiments provide direct evidence of the hydraulic processes that lead to strath terrace formation following perturbations to Qs/Qsc. Wobus et al. (2010) show that climate change induced incision was associated with a downstream incision wave due to changes in the relative sediment supply to transport capacity, while base-level induced (e.g, river capture, tectonics) incision was characterized by an upstream migrating incision wave. Crucially, our experiments show that channels in homogenous substrate respond to climatic perturbations through a complex multi-stage incision mechanism, containing a downstream (Fig. 3A) and upstream (Fig. 3C) wave component that both generate terraces, in the absence of any base level fall.

The multi-stage nature of the incision (Fig. 3) has important implications for studies that use the age of terraces to reconstruct climatic changes (e.g., Fuller et al., 2009) or rates of fluvial incision and tectonic uplift (e.g., Lavé and Avouac, 2001), due to the time transgressive nature of the terraces generated by this response (Zaprowski et al., 2001). During the downstream incision wave, the upstream parts of the alluvium are abandoned first, while the opposite is true during the upstream incision wave, leading to spatially variable terrace ages (Fig. 3D). If it is incorrectly assumed that the entire length of a terrace was abandoned at the same time, the average vertical incision rate calculated from a single terrace abandonment age would be misleading due to the failure to identify the erosion history of an incision wave and the spatially and temporally non-uniform nature of the river incision (Finnegan et al., 2014). Strategic sampling of high-resolution point ages from terraces may differentiate between strath terrace formation by vertical incision or knickpoint retreat (e.g., samples collected longitudinally from the same terrace surface; Baynes et al., 2015), allowing accurate interpretation of the mechanisms and triggering perturbations that generated them.

Knickpoints in a channel are traditionally interpreted as markers of either local lithological boundaries (e.g., Haviv et al., 2010), a history of base level fall or tectonic uplift rate variability (e.g., Finnegan, 2013), or threshold drainage areas for channel incision (Crosby and Whipple, 2006). However, our experiments indicate that the presence of a knickpoint in a channel with homogenous bedrock and constant baselevel is not necessarily diagnostic of any of these sources as knickpoints are generated following perturbations to Qs/Qsc (Fig. 3). Under normal conditions, flow in large natural alluvial rivers where strath terraces are 
commonly found is subcritical, but above-threshold supercritical flow conditions ( $F r>1)$ can occur due to a combination of driving factors including channel narrowing with variable width and increased discharge (SI Section 5). Base-level terraces are likely to have the same or a similar slope to the active channel bed through parallel knickpoint retreat (Finnegan, 2013), whereas terraces generated during the multi-stage response identified here are steeper than the active channel (Fig. 2, 3) due to new equilibrium conditions with lower sediment supply, higher discharge or continued tilting. An additional diagnostic link could be the highest terrace having a decreasing abandonment age with distance downstream (Fig. 3D) that does not occur during terrace formation driven by base-level fall. Thus, the morphology of terraces and spatial patterns of abandonment ages can be diagnostic of the processes and forcing perturbations that led to terrace generation and should be considered carefully when analyzing topography for the purpose of understanding and reconstructing past tectonic or climatic histories.

\section{CONCLUSIONS}

Landscapes are able to respond rapidly following climatic or anthropogenic perturbations that switch the erosion processes from one regime to another. The transition from lateral erosion and strath planation to channel narrowing, incision and strath terrace abandonment occurs through a multi-stage process of downstream then upstream incision waves. The headward passage of knickpoints can be initiated even in the absence of base level fall, due to the interaction between the channel bed and supercritical flow conditions. The passage of supercritical knickpoints provide an efficient process for the abandonment of strath terraces, and should be considered when using the presence of strath terraces within landscapes to infer past fluvial incision rates or climatic changes, which may be more spatially and temporally variable than previously thought.

\section{ACKNOWLEDGMENTS}

We thank F. Métivier for the loan of the sediment feeder, P. Davy for providing the Floodos code and T. Croissant for his help with the model runs. We thank J. Scheingross, A. Mather, A. Limaye and an anonymous reviewer for constructive comments that helped improve the final version of this manuscript. The research was funded by Marie Sklodowska-Curie Actions Individual Fellowship No. 703230 (to E.B).

\section{REFERENCES}

Baynes, E.R.C., Attal, M., Niedermann, S., Kirstein, L.A., Dugmore, A.J., and Naylor, M., 2015, Erosion during extreme flood events dominates Holocene canyon evolution in 
northeast Iceland: Proceedings of the National Academy of Sciences of the United States of America, v. 112, p. 2355-2360, https://doi.org/10.1073/pnas.1415443112.

Baynes E.R.C., Lague D., Attal M., Gangloff A., Kirstein L.A., Dugmore A.J., 2018, River selforganisation inhibits discharge control on waterfall migration: Scientific Reports 8, 2444, https://doi:10.1038/s41598-018-20767-6

Bull, W.B., 1990, Stream-terrace genesis: Implications for soil development: Geomorphology, v. 3, p. 351-367, https://doi.org/10.1016/0169-555X(90)90011-E.

Crosby, B.T., and Whipple, K.X., 2006, Knickpoint intiation and distribution within fluvial networks: 236 waterfalls in the Waipaoa River, North Island, New Zealand: Geomorphology, v. 82, p. 16-38, https://doi.org/10.1016/j.geomorph.2005.08.023.

Davy, P., Croissant, T., and Lague, D., 2017, A precipiton method to calculate river hydrodynamics, with applications to flood prediction, landscape evolution models and braiding instabilities: Journal of Geophysical Research. Earth Surface, v. 122, p. 1491-1512, https://doi.org/10.1002/2016JF004156.

Dubinski, I.M., and Wohl, E., 2013, Relationships between block quaryying, bed shear stress, and stream power: A physical model of block quarrying of a jointed bedrock channel: Geomorphology, v. 180-181, p. 66-81, https://doi.org/10.1016/j.geomorph.2012.09.007.

Finnegan, N.J., 2013, Interpretation and downstream correlation of bedrock river terrace treads created from propagating knickpoints: Journal of Geophysical Research. Earth Surface, v. 118, p. 54-64, https://doi.org/10.1029/2012JF002534.

Finnegan, N.J., and Dietrich, W.E., 2011, Episodic bedrock strath terrace formation due to meander migration and cutoff: Geology, v. 39, p. 143-146, https://doi.org/10.1130/G31716.1.

Finnegan, N.J., and Balco, G., 2013, Sediment supply, base level, braiding, and bedrock river terrace formation: Arroyo Seco, California, USA: Geological Society of America Bulletin, v. 125, p. 1114-1124, https://doi.org/10.1130/B30727.1.

Finnegan, N.J., Schumer, R., Finnegan, S., 2014, A signature of transience in bedrock river incision rates over timescales of 104-107 years: Nature, v. 505, p. 391-394, https://doi:10.1038/nature12913

Fuller, T.K., Perg, L.A., Willenbring, J.K., and Lepper, K., 2009, Field evidence for climatedriven changes in sediment supply leading to strath terrace formation: Geology, v. 37, p. 467-470, https://doi.org/10.1130/G25487A.1. 
Hancock, G.S., and Anderson, R.S., 2002, Numerical modelling of fluvial strath-terrace formation in response to oscillating climate: Geological Society of America Bulletin, v. 114, p. $1131-1142$.

Hasbargen, L.E., and Paola, C., 2000, Landscape instability in an experimental drainage basin: Geology, v. 28, p. 1067-1070, https://doi.org/10.1130/00917613(2000)28<1067:LIIAED>2.0.CO;2

Haviv, I., Enzel, Y., Whipple, K.X., Zilberman, E., Matmon, A., Stone, J., and Fifield, K.L., 2010, Evolution of vertical knickpoints (waterfalls) with resistant caprock: Insights from numerical modelling: Journal of Geophysical Research, v. 115, p. F03028, https://doi.org/10.1029/2008JF001187.

Hooke, R. 1968, Model Geology: Prototype and Laboratory Streams: Discussion: Geological Society of America Bulletin, v. 79, p. 391-94, https://doi.org/10.1130/0016-

Izumi, N., Yokokawa, M., and Parker, G., 2017, Incisional cyclic steps of permanent form in mixed bedrock-alluvial rivers: Journal of Geophysical Research. Earth Surface, v. 122, p. 130-152, https://doi.org/10.1002/2016JF003847.

Johnson, J.P.L., and Whipple, K.X., 2007, Feedbacks between erosion and sediment transport in experimental bedrock channels: Earth Surface Processes and Landforms, v. 32, p. 1048-1062, https://doi.org/10.1002/esp.1471.

Lavé, J., and Avouac, J.P., 2001, Fluvial incision and tectonic uplift across the Himalayas of central Nepal: Journal of Geophysical Research, v. 106, p. 26561-26591, https://doi.org/10.1029/2001JB000359.

Limaye, A.B.S., and Lamb, M.P., 2016, Numerical model predictions of autogenic fluvial terraces and comparison to climate change expectations: Journal of Geophysical Research. Earth Surface, v. 121, p. 512-544, https://doi.org/10.1002/2014JF003392.

Mackey, B.H., Scheingross, J.S., Lamb, M.P., and Farley, K.A., 2014, Knickpoint formation, rapid propagation, and landscape response following coastal cliff retreat at the last interglacial sea-level highstand: Kaua'i, Hawai'i: Geological Society of America Bulletin, v. 126, p. 925-942, https://doi.org/10.1130/B30930.1. eustasy: A guide to interpreting fluvial terraces: Journal of Geophysical Research, v. 99, p. 14031-14050, https://doi.org/10.1029/94JB00857. 
Parker, G., and Izumi, N., 2000, Purely erosional cyclic and solitary steps created by flow over a cohesive bed: Journal of Fluid Mechanics, v. 419, p. 203-238, https://doi.org/10.1017/S0022112000001403.

Pazzaglia, F.J., Gardner, T.W., and Merritts, D., 1998, Bedrock fluvial incision and longitudinal profile development over geologic time scales determined by fluvial terraces, in Wohl, E., and Tinkler, K., eds., Bedrock channels: American Geophysical Union Geophysical Monograph Series 107, p. 207-235, https://doi.org/10.1029/GM107p0207.

Scheingross, J.S., and Lamb M.P., 2017, A mechanistic model of waterfall plunge-pool erosion into bedrock, Journal of Geophysical Research. Earth Surface, v. 122, p. 2079-2104, https://doi:10.1002/2017JF004195.

Schumm, S.A., and Parker, R.S., 1973, Implications of Complex Response of Drainage Systems for Quaternary Alluvial Stratigraphy: Nature, v. 243, p. 99-100.

Stokes, M., Mather, A.E., and Harvey, A.M., 2002, Quantification of river-capture-induced base-level changes and landscape development, Sorbas Basin, SE Spain: Geological Society of London, Special Publications, v. 191, p. 23-35, https://doi.org/10.1144/GSL.SP.2002.191.01.03.

Stokes, M., Mather, A.E., Belfoul, M., Faik, F., Bouzid, S., Geach, M.R., Cunha, P.P., Boulton, S.J., and Thiel, C., 2017, Controls on dryland mountain landscape development along the NW Saharan desert margin: Insights from Quaternary river terrace sequences(Dades River, south-central High Atlas, Morocco): Quaternary Science Reviews, v. 166, p. 363-379, https://doi.org/10.1016/j.quascirev.2017.04.017.

Turowski J.M., 2007, Controls on bedrock channel morphology: experimental and theoretical investigations and comparison with natural channels, University of Cambridge PhD Thesis (http://ethos.bl.uk/OrderDetails.do?uin=uk.bl.ethos.613289).

Turowski J.M., Lague D., Hovius N., Crave A., 2005, Dynamics and steady-state geometry of an experimental channel incising cohesive material; Geophysical Research Abstracts. EGU General Assembly 2005, Apr 2005, Vienna, Austria. European Geosciences Union, pp.EGU05-A-05294, 2005, Vol 7

Turowski, J.M., Lague, D., Crave, A., and Hovius, N., 2006, Experimental channel response to tectonic uplift: Journal of Geophysical Research, v. 111, F03008, https://doi.org/10.1029/2005JF000306.

Wegmann, K.W., and Pazzaglia, F.J., 2002, Holocene strath terraces, climate change, and active tectonics: The Clearwater River basin, Olympic Peninsula, Washington State: 
Geological Society of America Bulletin, v. 114, p. 731-744, https://doi.org/10.1130/00167606(2002)114<0731:HSTCCA>2.0.CO;2.

Wobus, C.W., Tucker, G.E., and Anderson, R.S., 2010, Does climate change create distinctive patterns of landscape incision?: Journal of Geophysical Research, v. 115, p. F04008, https://doi.org/10.1029/2009JF001562.

Wohl, E., 2008, The effect of bedrock jointing on the formation of straths in the Cache la Poudre River drainage, Colorado Front Range: Journal of Geophysical Research, v. 113, p. F01007, https://doi.org/10.1029/2007JF000817.

Yokokwa, M., Kotera, A., Kyogoku, A., and Izumi, N., 2013, Cyclic steps by bedrock incision, in Fukuoka, S., et al., eds., Advances in River Sediment Research: The Netherlands, CRC Press, p. 629-633.

Zaprowski, B.J., Evenson, E.B., Pazzaglia, F.J., and Epstein J.B., 2002, Knickzone propagation in the Black Hills and northern High Plains: A different perspective on the late Cenozoic exhumation of the Laramide Rocky Mountains, Geology, v. 29, p. 547-550, https://doi:10.1130/0091-7613(2001)029<0547:kpitbh>2.0.co;2.

\section{FIGURES}

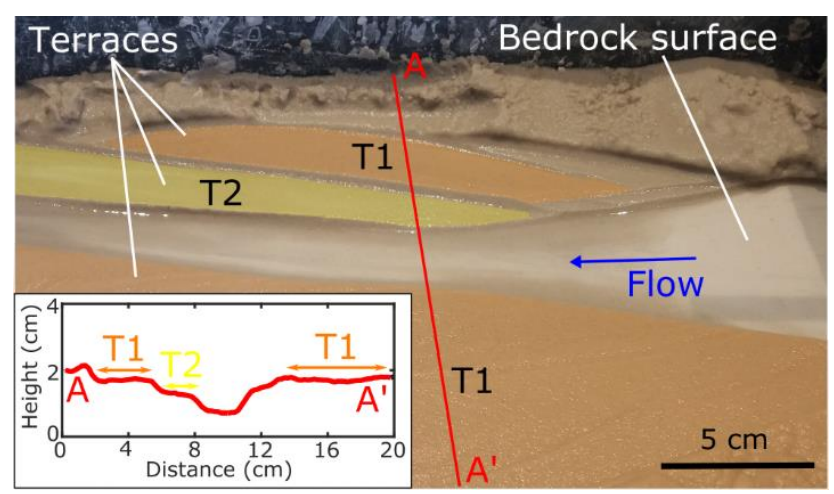

Figure 1.: Example of terraces generated in the experiments. The white surface is the silica paste acting as cohesive bedrock and the brown material is sand, acting as coarse material transported as bedload. Progressive channel incision and channel narrowing leads to the abandonment of the previously active river bed, preserved as strath terraces. Inset shows topographic cross-section from A to A', with terraces labeled in yellow and orange. 



327

328

329

330

331

332

333

334

335

336

337

338

339

340

341

342

343

344

345

346

347

348

Figure 2. (A). Extracted long profiles during experiment 1. Green line ( $t=11 \mathrm{~min})$ shows the profile of the alluvial river, with the subsequent stripping of the sediment cover progressively exposing the bedrock surface within the channel. Black solid line ( $t=171 \mathrm{~min})$ shows the final long profile. Grey dashed lines indicate the location of preserved terraces at the end of the experiment. Instabilities form mid-channel, developing into a single knickpoint step that propagates upstream. (1): Initial alluvial channel. (2): Downstream stripping of alluvial cover. (3): Cyclic step development. (4): Knickpoint retreat in headward direction. (B): Evolution of channel width (lines) and rate of vertical elevation change (crosses) through time for the experiments (expt 1 = black, expt 2 = blue, expt 3 = red) at a cross-section $25 \%$ distance from the channel inlet. Width is plotted using a 10 point moving average and elevation change is plotted using a 5 point moving average. Dashed vertical lines indicates the timing of the perturbation in experiments 1 and 2 at 37 mins (gray), and the timing of the presence of a knickpoint (colored lines). After the perturbation, there was a reduction in channel width during both experiments 1 and 2. Focusing of the flow into a single thread occurred due to the gradual tilting in experiment 3 . There was a short period of channel widening between 150 and 175 min associated with the erosion of the sediment deposited at the inlet during the initial stages, unrestricting the flow and inundating a larger area and an apparent increase in the channel width. The highest incision rates are associated with (i) the rapid downstream stripping of sediment and (ii) the headward migration of a knickpoint through bedrock.

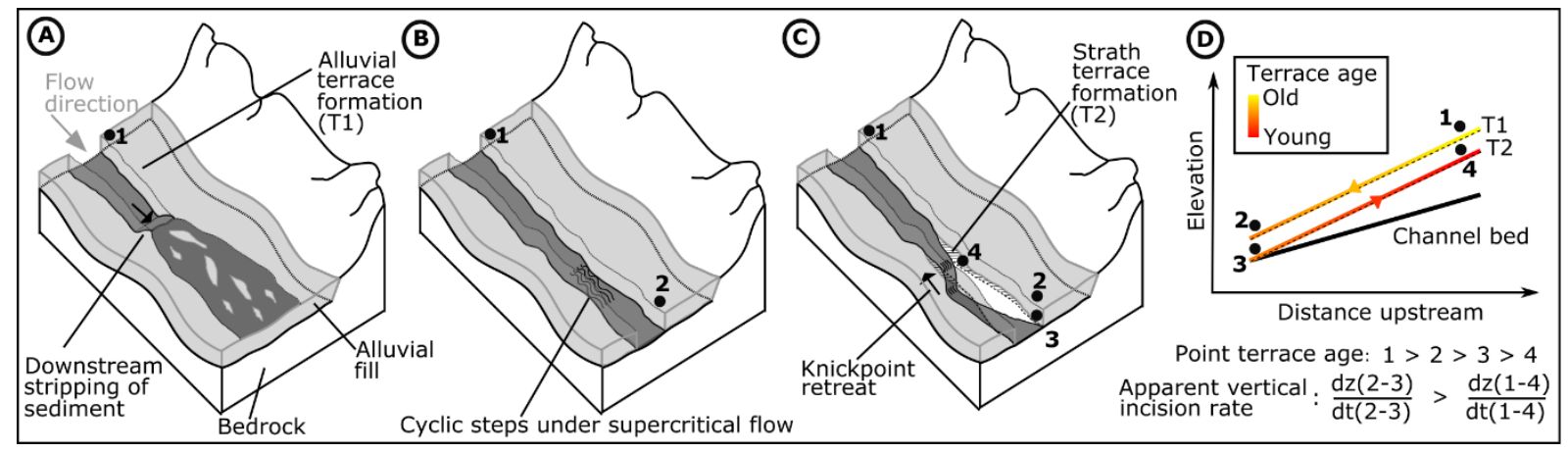

Figure 3. Conceptual model showing the stages of supercritical terrace formation. (A) Downstream stripping of sediment cover following perturbation to Qs/Qsc. (B) Under 
349 supercritical flow conditions, the channel bed destabilizes into series of cyclic steps. (C)

350 Cyclic steps develop into a 'supercritical knickpoint', which migrates in an upstream direction

351 abandoning a 'supercritical river terrace'. Channel narrows at knickpoint, and widens

352 downstream. (D) Conceptual representation of the elevation of the channel bed and

353 corresponding terraces following response shown in (A-C). Arrows on terraces indicate the

354 direction of the incision wave that abandoned them. The upstream part of $T 1$ is abandoned

355 first by the downstream migrating incision wave, and the downstream part of T2 is

356 abandoned first by the upstream migrating knickpoint. Vertical incision rates calculated from

357 point terraces ages (1-4 and 2-2) provide misleading spatial variation in vertical incision, as

358 the majority of the incision actually occurs through the passage of the supercritical

359 knickpoint. 


\section{Supplementary Information}

\section{SI Section 1: Relevance of experiments for natural channels and experimental setup.}

Experimental modelling studies of landscape and fluvial dynamics are typically performed using one of two approaches. The first directly scales the experimental prototype to the natural system by ensuring that non-dimensional hydraulic parameters such as the Froude number are scaled strictly and the physical processes (e.g., sediment transport) are the same in both the experimental and natural systems. The second approach relaxes this strict scaling, and seeks a 'similarity of process' between the experiment and the natural channel (Hooke, 1968) whereby the behaviour of the processes within the experiment system are qualitatively similar and 'reasonably effective' at replicating the behaviour of natural systems despite large differences in the governing dimensionless numbers (Paola et al., 2009). This second approach has the benefit of allowing temporal and spatial timescales to be relaxed, as materials such as silica cement that is eroded by clear water flow can be used to replicate bedrock, and experiments exploring bedrock erosion processes can be performed relatively quickly. It should be noted that the results from these experiments cannot be directly scaled up to any particular natural system. Additionally, the experimental channel is always 'active', and the experiments do not include the periods of time between flood events when the channel is not being eroded, creating a difficulty when exploring relative timescales of geomorphic response between the experiments and natural rivers. However, processes such as flow acceleration above the knickpoint lip, cyclic step development, plunge pool erosion, undercutting of the knickpoint face and channel banks, cantilever failure, erosion and transport of cohesive material by hydraulic shear are present in the experiments. The typical width-depth ratio of the experimental channels at the start of the experiments (alluvial channel conditions) is $50-80$, similar to that of natural gravel-bedded rivers (Finnegan et al., 2005), and the scaling of the channel width with discharge observed in natural rivers is also reproduced in the experiment. Therefore, we can be confident that the experiments are 'reasonably effective' in replicating natural processes, and the response of the channels to the perturbations (sediment supply, discharge or slope) in the experiments can help inform the response of natural channels to similar forcing.

Figure S1 shows the setup used during our experiments in the Bedrock River Experimental Incision Tank at the Université de Rennes. The initial alluvial cover was composed of wellsorted sand (grain size $=250 \mu \mathrm{m}$ ), and the homogenous cohesive silica paste used as a bedrock simulant was composed of $61.5 \%$ angular silica, $20.5 \%$ spherical beads and $18 \%$ water. The silica paste was mixed in a cement mixer before being transferred into the box flume and homogenised using a high frequency vibrating needle to re-liquefy the paste (see 
Baynes et al., 2018 for further details related to the properties of the silica paste and the preparation procedure). Flow in the channel is typically laminar with low Reynolds numbers $(<1000)$, and is input into the channel through a reservoir and the discharge magnitude controlled using a pump.

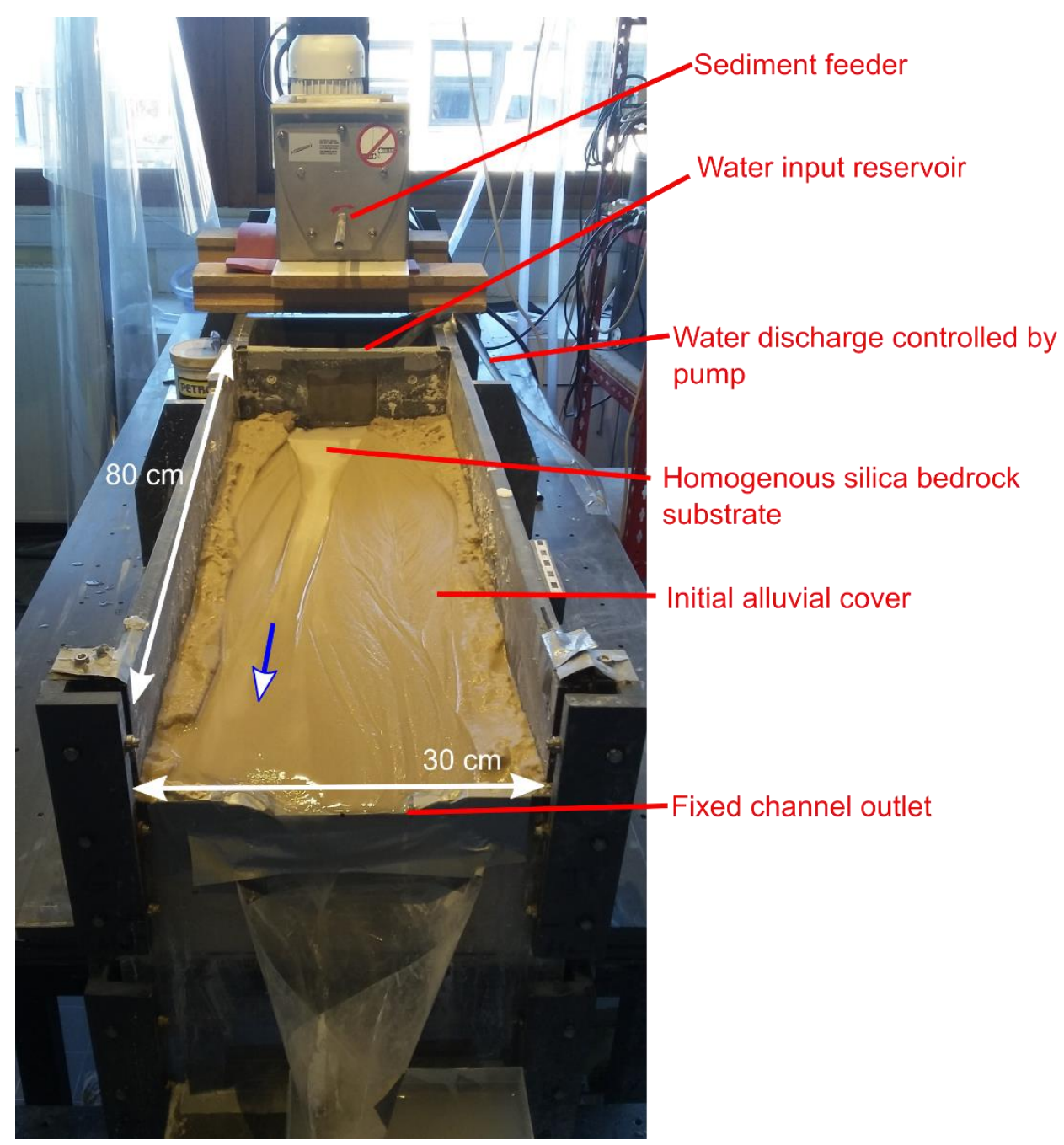

400

Fig. S1: Photograph of the Bedrock River Experimental Incision Tank at Université de Rennes. The blue arrow shows the flow direction within the channel.

\section{SI Section 2: Floodos parameters}

Floodos is a numerical precipiton-based hydrodynamic model (see Davy et al., 2017 for full technical description of the model), and was used here to assess the hydraulic conditions during the experiments. The input topography for Floodos was produced directly by gridding the point clouds, collected from the terrestrial laser scanner at regular time intervals during the experiments, with a pixel size of $2 \mathrm{~mm}$. Floodos was run using the laminar flow option consistent with the relatively low Reynolds number of the experiment $(<1000)$ across most of the channel under alluvial conditions (Fig. S2). 

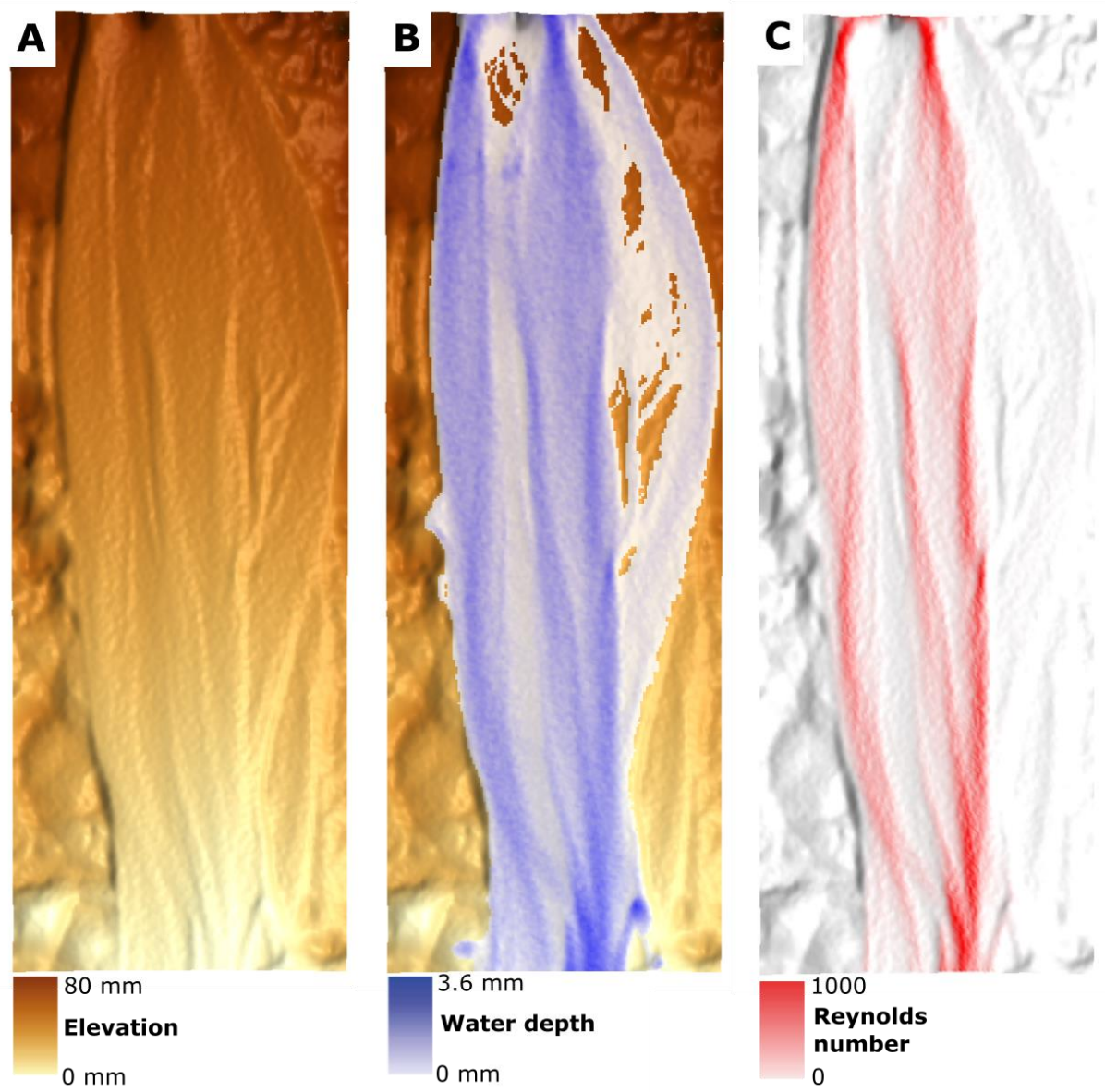

Fig. S2: (A) Digital Elevation Model from Experiment 1, when the channel is under fully alluvial conditions ( $t=33$ minutes).

(B) Modelled water depth mask using Floodos hydrodynamic model (Davy et al., 2017). (C) Calculated Reynolds number for each pixel of the flow, using the Floodos model output.

Under the laminar flow conditions, the local vertically averaged velocity $U$ is approximated by:

$$
U=C H^{2} S
$$
where $\mathrm{C}$ if a friction coefficient in $\left[\mathrm{L}^{-1} \cdot \mathrm{T}^{-1}\right], \mathrm{H}$ is local water depth and $\mathrm{S}$ is the local channel slope. Equation $\mathrm{S} 1$ is obtained by integrating vertically a laminar flow velocity profile assuming steady-uniform flow. In pure laminar flow, $\mathrm{C}$ is entirely set by the water viscosity $\mu$ and should be approximately $C \sim \rho g / 3 \mu$ where $\rho$ is water density and $g$ is gravitational acceleration. This predicts that at $10^{\circ} \mathrm{C}, \mathrm{C} \sim 2.5 \times 10^{6} \mathrm{~m}^{-1} \cdot \mathrm{s}^{-1}$. Fig. S2 shows the impact of different values of $\mathrm{C}$ on the predicted extent of water flowing over a flat surface compared to manual measurements of the wetted area obtained from a photograph taken from above the experiment (Fig. S3A). The simulations of flow extent are relatively similar for all modelled 
values of $\mathrm{C}$, although lower values of $\mathrm{C}$ predict a greater level of overflow on the edges in the downstream part. We therefore used the value of $C\left(2.5 \times 10^{6} \mathrm{~m}^{-1} . \mathrm{s}^{-1}\right)$ for the simulations presented here, due to good consistency with the manual measurements and the theoretical prediction of the friction coefficient based on the water viscosity for flow over a flat surface (Fig. S3) and for channelised flow (Fig. S4).

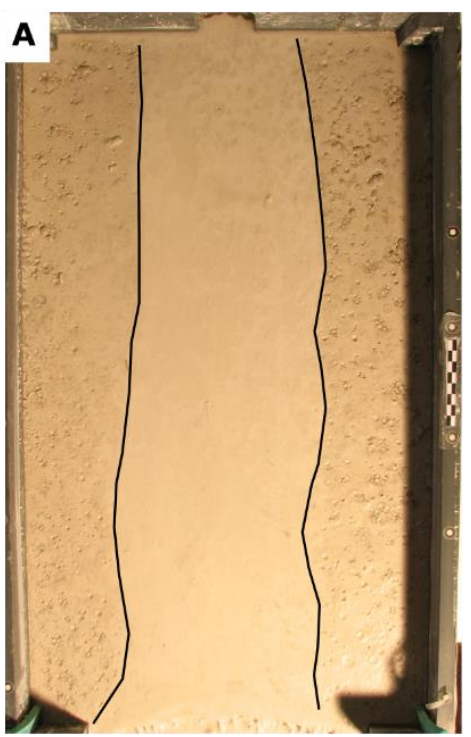

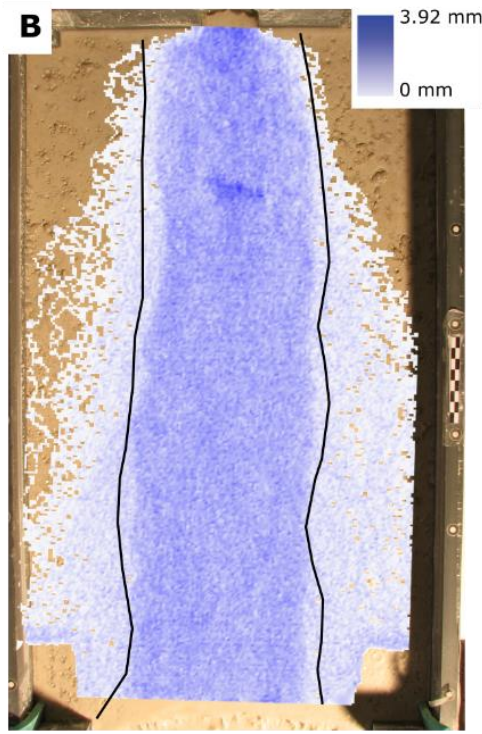

$C=1.0 \times 10^{6} \mathrm{~m}^{-1} \mathrm{~s}^{-1}$

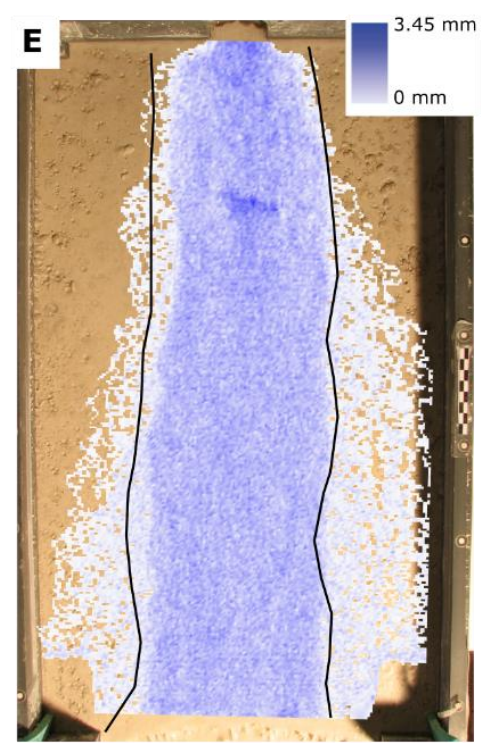

$\mathrm{C}=2.5 \times 10^{6} \mathrm{~m}^{-1} \mathrm{~s}^{-1}$

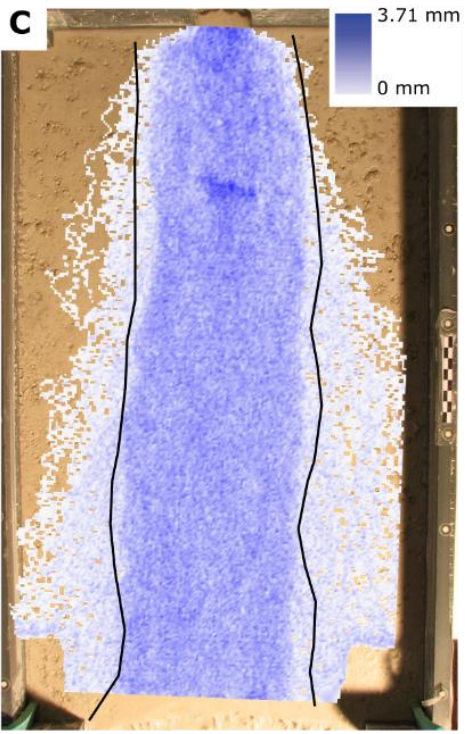

$\mathrm{C}=1.5 \times 10^{6} \mathrm{~m}^{-1} \mathrm{~s}^{-1}$



$C=3.0 \times 10^{6} \mathrm{~m}^{-1} \mathrm{~s}^{-1}$

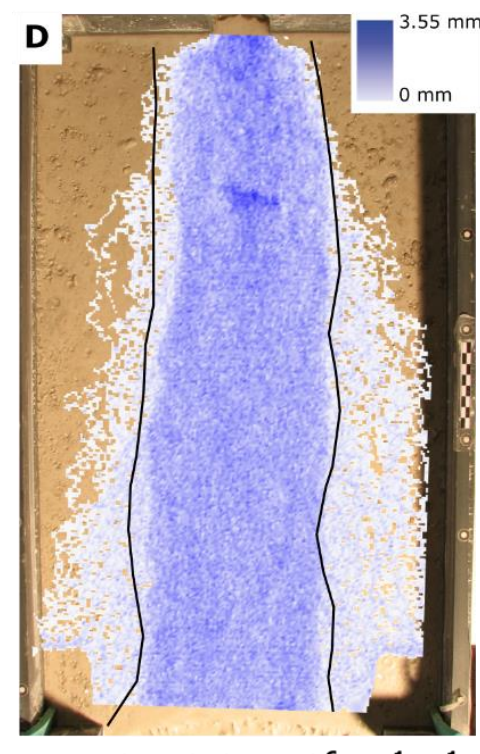

$$
\mathrm{C}=2.0 \times 10^{6} \mathrm{~m}^{-1} \mathrm{~s}^{-1}
$$

Fig. S3: (A) Photograph of water flowing over a flat surface (slope $=3.3^{\circ}, Q=1 \mathrm{l} / \mathrm{min}$ ), with black lines indicating edge of water extent measured manually from the image. Flow is from top to bottom in the image. (B-F) Floodos hydrodynamic model output using laminar flow option and different values of the friction coefficient. Black lines are the same as (A) and shown for comparison of modelled against observed flow extent. The predicted theoretical 


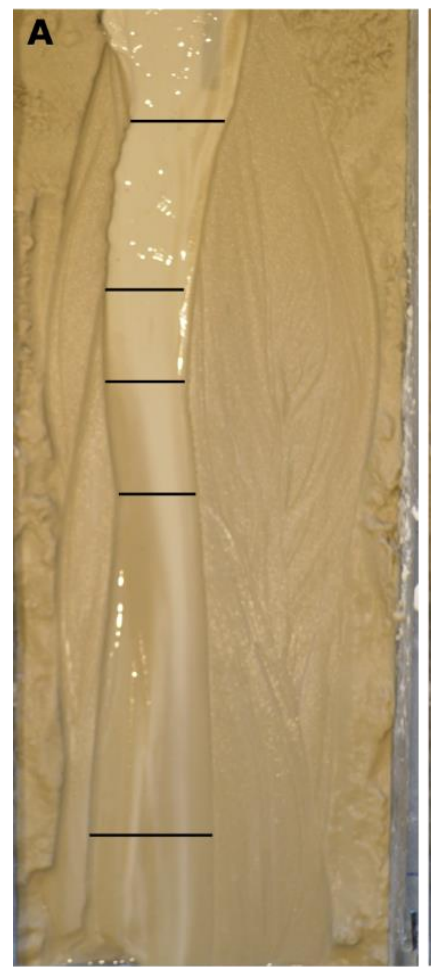

value of the friction coefficient $\left(2.5 \times 10^{6} \mathrm{~m}^{-1} \mathrm{~s}^{-1}\right)$ has a good match with the observed flow extent. For this value, the lateral areas where overflow occurs have flow depth that are extremely low $(<0.1 \mathrm{~mm})$ and represent a negligible fraction of the total discharge.

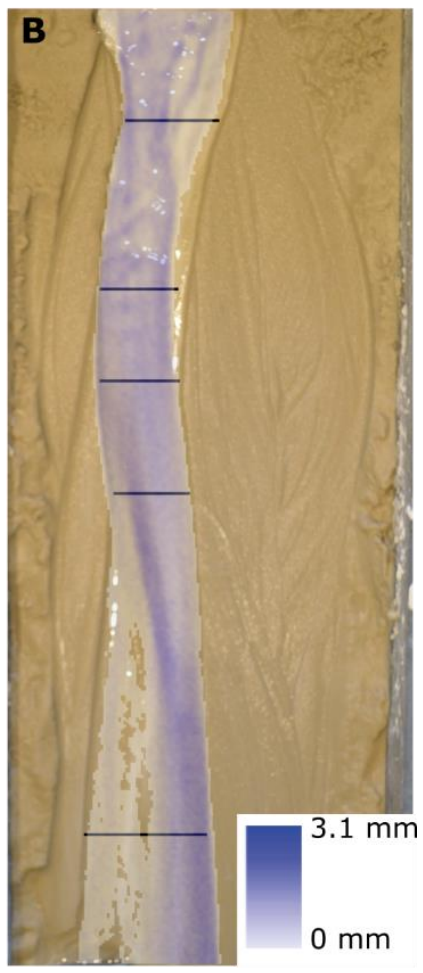

Fig. S4: (A) Photograph of experiment 1 ( $t=66$ mins), with wetted area indicated by the black bars. Flow is from top to bottom in the image. (B) Floodos model water mask coloured by water depth, using friction coefficient of $2.5 \times 10^{6} \mathrm{~m}^{-1} \mathrm{~s}^{-1}$, for the same time period overlain over the photograph, with the same black bars from (A). The Floodos water mask closely matches the manual measurements of channel width from the photograph throughout the length of the channel. At the left hand side in the downstream reach, a terrace is starting to be abandoned, hence the very low flow depths in this region.

\section{SI Section 3: Evolution of channel and terrace geometry during experiments}

This SI section provides the complete experimental data for the evolution of the channel geometry for each of the three experiments. The long profiles were extracted by finding the point of minimum elevation for each row of the grid (Fig. S5). Terraces were defined from the DEM as flat surfaces (elevation within $1 \mathrm{~mm}$ ) and at least $2 \mathrm{~cm}$ wide. The channel crosssections (Fig. S6) were extracted from the data at the location of the grid that was $25 \%$ of the distance from the inlet to the outlet of the channel. 

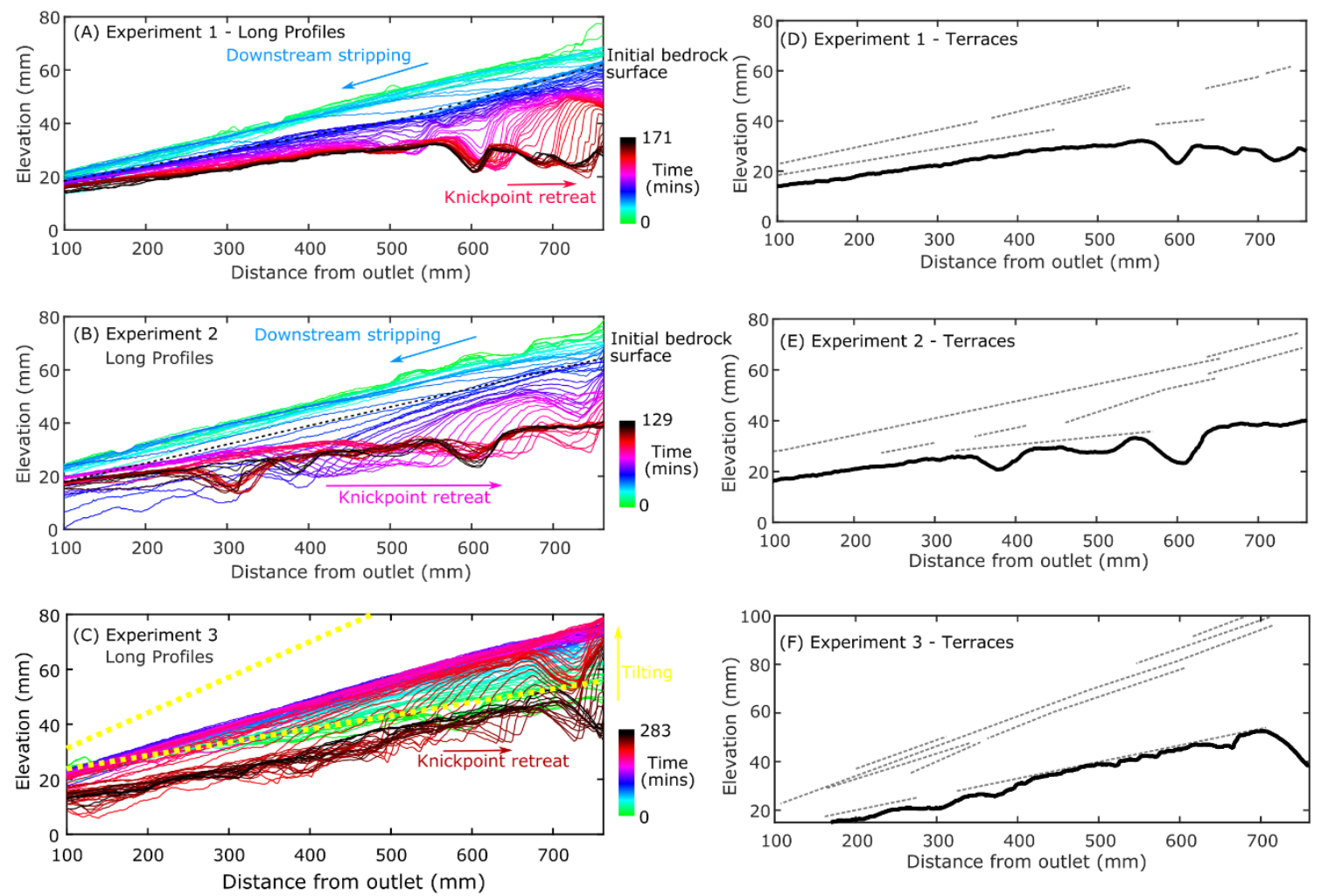

Fig. S5: $(A-C)$ Extracted long profiles from the three experiments. $(A)$ Experiment 1, where the input sediment flux was stopped after 37 minutes (80 profiles in total). (B) Experiment 2, where the discharge was doubled to $3 \mathrm{I} / \mathrm{min}$ after 37 minutes (61 profiles in total). (C)

464 Experiment 3, where the slope was increased at $1^{\circ}$ per 60 minutes from an initial slope of $2^{\circ}$ for 280 minutes (132 profiles in total). The colour of the lines indicates the evolution during the experiments. The dashed yellow lines in (C) show the initial slope of the experiment $467\left(2.5^{\circ}\right)$, and the projected slope of the channel at the end of the tilting if there had been no 468 erosion of the alluvial cover or bedrock $\left(7.2^{\circ}\right)$. The maximum slope achieved in the channel 469 before the onset of the incision of bedrock was $\sim 4.5^{\circ}$. Grey dashed lines in $(A)$ and $(B)$ 470 indicate the elevation of the bedrock surface at the start of each experiment, to show the 471 transition from alluvial stripping and bedrock incision. The same line is not shown in (C) as 472 the elevation of the bedrock surface changed during the course of the experiment due to the 473 tilting. (D-F) Preserved terrace surfaces at the end of each experiment. Solid lines indicate 474 the long profile of the active channel, and dashed lines indicate the location and elevation of 475 terraces. The slope of the upper terraces is greater than the incised active channel. 

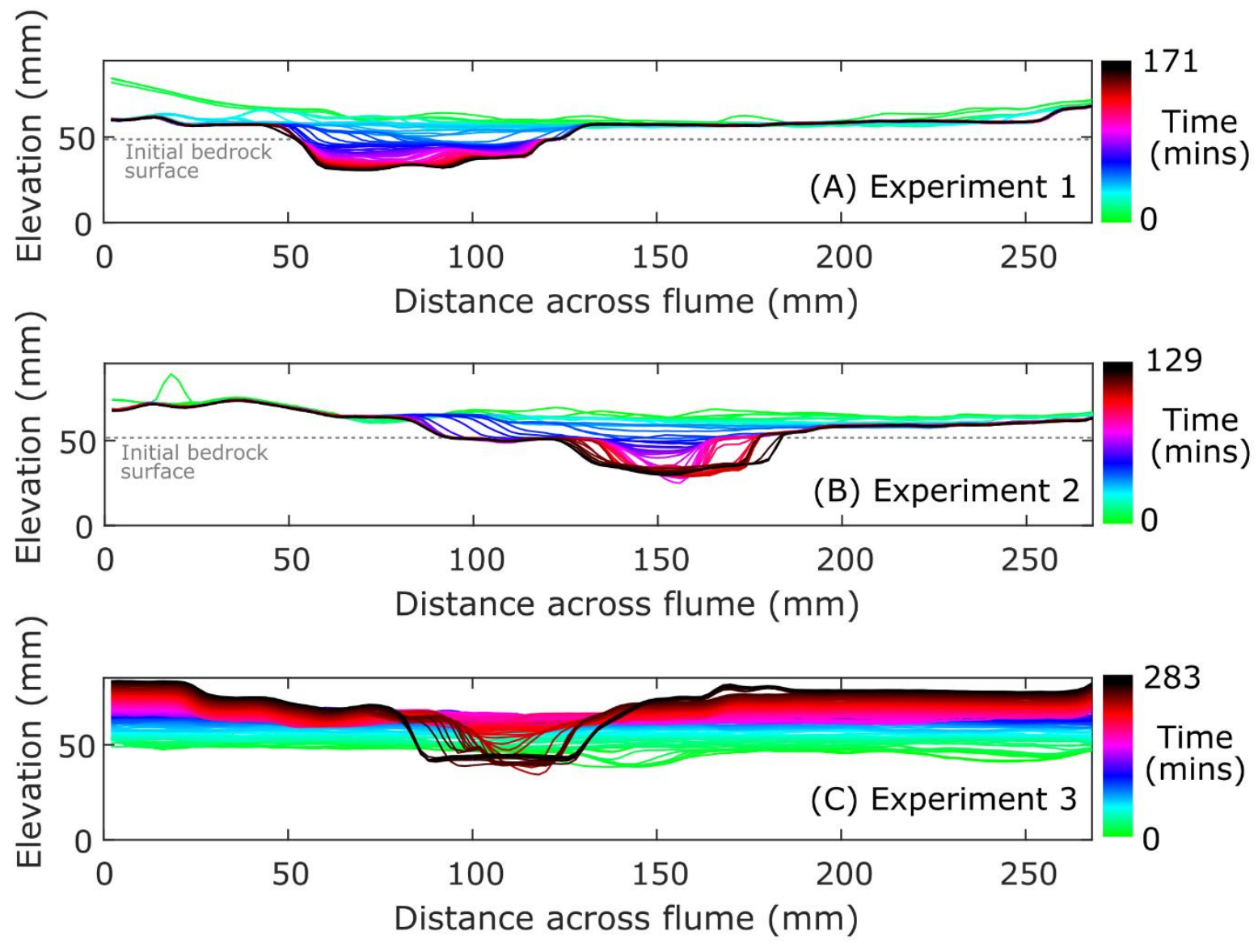

Fig. S6: Evolution of channel cross-sections at the $25 \%$ position from the water inlet. Crosssections were extracted from this location to ensure it was located over an area that experienced incision and the development and propagation of a knickpoint. Colours represent the same time points as Fig. S1. It can be seen that channel incision occurred under narrow channel width conditions, followed by lateral erosion of the banks leading to channel widening and minor channel aggradation in experiments 2 and 3. Grey dashed lines in $(A)$ and $(B)$ indicate the elevation of the bedrock surface at the start of each experiment, to show the transition from alluvial stripping and bedrock incision. The same line is not shown in (C) as the elevation of the bedrock surface changed during the course of the experiment due to the tilting.

\section{SI Section 4: Demonstration of the incisional efficiency of the headward erosion} process and width-incision coupling

Here, we provide further analysis to demonstrate the bedrock erosional efficiency of the headward migration of knickpoints compared to the vertical erosion by hydraulic shear upstream of the knickpoint lip (Fig. S7). Fig. S7A shows selected long profiles from experiment 1 and Fig. S8B shows the rate of elevation change along the profiles between the 
495 time steps. The largest rates of bedrock elevation change correspond to the locations and 496 time periods when the knickpoint is migrating upstream.

(A)
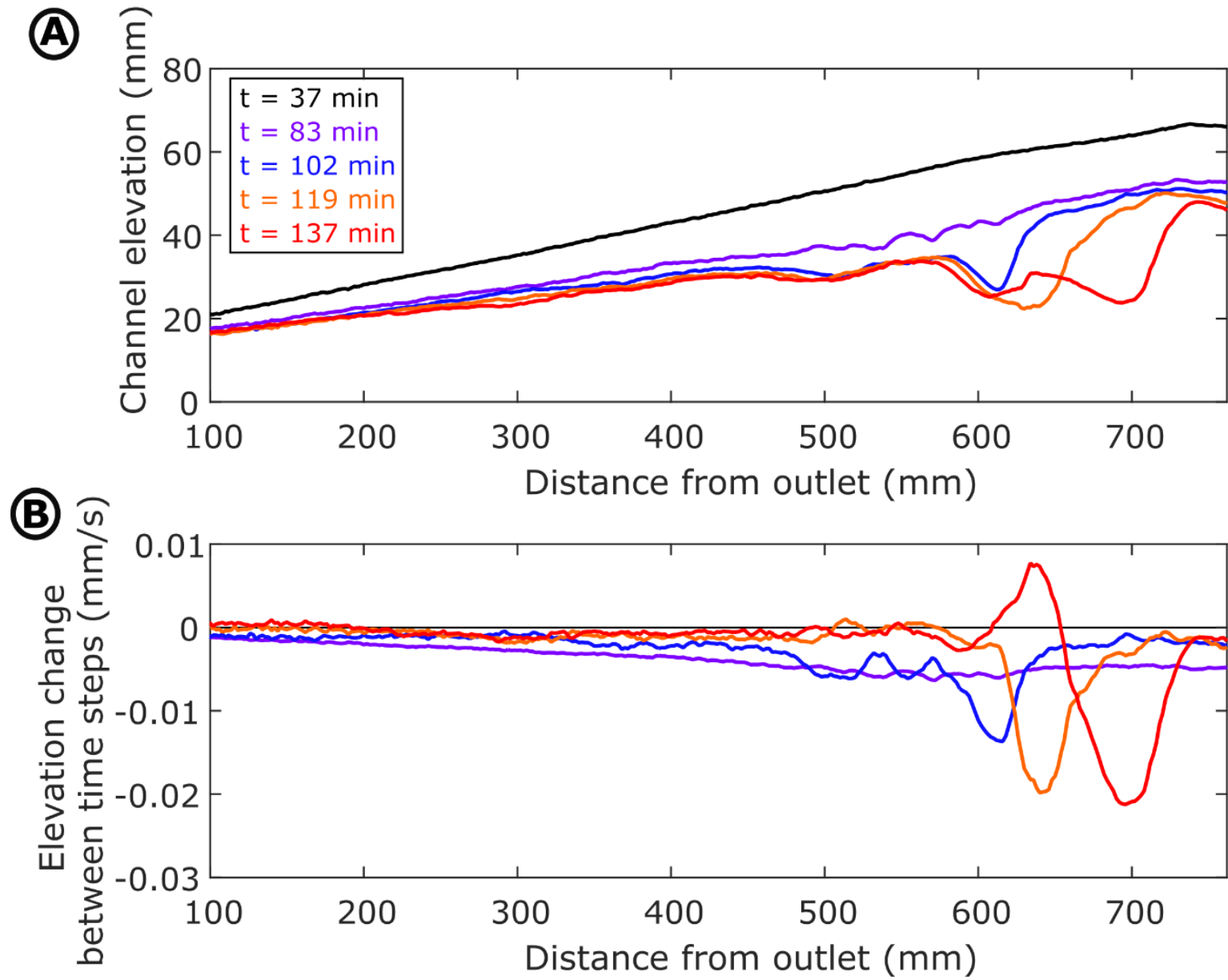

497

Fig. S7: (A) Selected long profiles showing alluvial channel just before sediment supply stopped ( $t=37$ min; black), channel containing cyclic steps, after sediment has been stripped away from the bedrock profile ( $t=83 \mathrm{~min}$; purple) and then three long profiles from different stages of knickpoint retreat ( $t=102,119,137$ min; blue, orange and red, respectively). (B) The variation in rate of elevation change with distance along the channel between the different time steps. The consistently high rate of elevation change from $t=37$ minutes to $t=$ 83 minutes (purple line) corresponds to the time period when the alluvial cover was being stripped downstream.

506

\section{SI Section 5:}


'Supercritical knickpoints' were generated during the experiments in the absence of any base

510 level fall, after the development of instabilities in the channel bed possibly associated with

511 supercritical flow conditions, when the Froude number $\left(\mathrm{Fr}=\mathrm{U} /(\mathrm{gH})^{0.5}\right)$, is > 1 (Fig. S9; Parker

512 and Izumi, 2000). In this section, we used the Floodos hydrodynamic model output to

513 calculate the Froude number for all locations within the channel (Fig. S8) for selected times

514 of experiment $1(t=81 \mathrm{~min}$, when bed instabilities were developing; Fig. S8A, and $t=106$

515 min, when a single knickpoint had formed; Fig. S8B).

516 Cyclic steps form under supercritical flow conditions due to an interaction between the

517 channel bed and the flow above it (Izumi et al., 2017), developing a series of steps with

518 transcritical flow that alternates between supercritical and subcritical flow with hydraulic

519 jumps (Fig. S8A). After a single knickpoint formed, a pronounced change in the Froude

520 number and a hydraulic jump is present at the knickpoint lip, with subcritical flow conditions

521 present in the plunge pool downstream (Fig. S8B). The absolute values of Fr are possibly

522 slightly overestimated due to the use of the laminar flow option in Floodos, and some

523 uncertainty related to whether the flow is purely laminar or transitional (Fig. S2). However,

524 the pattern of Fr variation is consistent with cyclic step development as observed and

525 predicted theoretically under supercritical flow conditions (Parker and Izumi, 2000; Izumi et

526 al., 2017).

527 

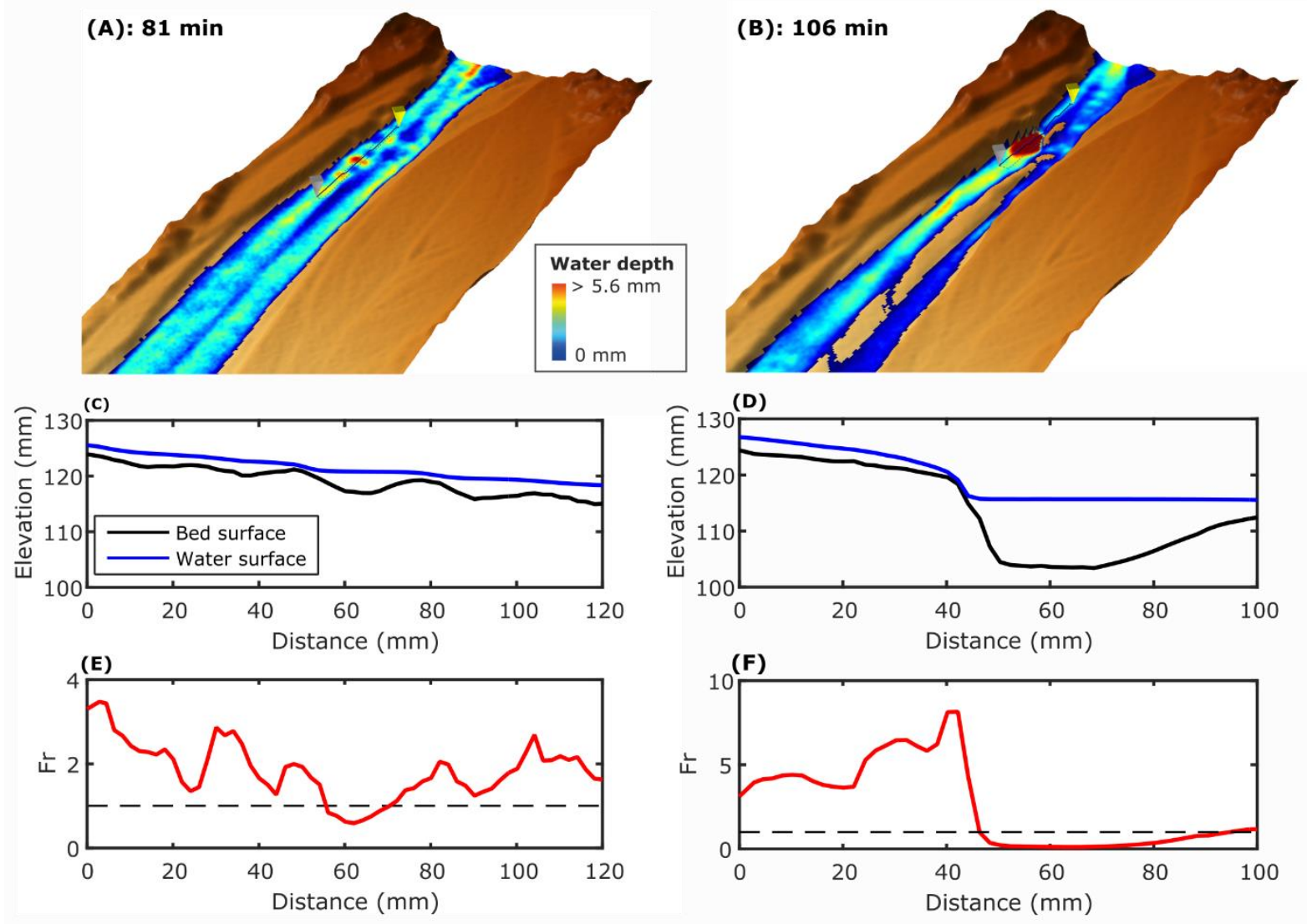

Fig. S8: Exploration of flow conditions during the development of the self-formed knickpoints. (A-B) Topography during the experiments at selected time steps, with the colours indicating the water depth. (C-D) Profiles for the bed and water surfaces for the reach along the black lines in $(A)$ and $(B)$. (E-F) Extracted Froude number along the same reach as the $(C)$ and $(D)$.

\section{Supercritical flow in natural rivers}

Here, we performed a simple test to consider whether supercritical flow conditions can be sustained in natural rivers under steady, uniform flow, by exploring the impact of varying channel width and discharge on the Froude number, assuming a rectangular channel with a

538 constant slope.

539 The flow velocity can be estimated using the Manning's equation $\left(U=n^{-1} \cdot H^{2 / 3} \cdot S^{0.5}\right)$, where $n$ 540 is the Manning's roughness coefficient, $\mathrm{H}$ is the flow depth, and $\mathrm{S}$ is the channel slope. The 541 flow velocity is also given by $U=Q / W H$, where $Q$ is the discharge and $W$ is the channel 542 width. Substituting these two equations into each other gives the following equation for the 543 flow depth:

$544 \quad H=\left(n \frac{Q}{W}\right)^{\frac{3}{5}} S^{-\frac{3}{10}}$ 
The Froude number is calculated from the flow velocity, the acceleration due to gravity $(\mathrm{g})$ and the flow depth: $\left(\mathrm{Fr}=\mathrm{U} /(\mathrm{gH})^{0.5}\right)$. Substituting equation $\mathrm{S} 2$ into this equation gives the following relationship between the Froude number and the discharge, slope, width and Manning's roughness coefficient:

$F r=Q^{\frac{1}{10}} S^{\frac{9}{20}} W^{-\frac{1}{10}} n^{-\frac{9}{10}} g^{-\frac{1}{2}}$

Eq (S3) shows that in steady uniform flow conditions, the Froude number is mostly sensitive to slope and roughness, with a weak dependency on width and discharge.

According to Parker et al., (2007), the channel width and channel slope of a gravel bed river at bankfull discharge conditions can be calculated using the following equations:

$W_{b f}=\frac{4.63}{g^{\frac{1}{5}}} Q_{b f}^{0.4}\left(\frac{Q_{b f}}{\left.\sqrt{g D_{50} D_{50}}\right)^{0.0667}}\right.$

$S_{b f}=0.101\left(\frac{Q_{b f}}{\sqrt{g D_{50}} D_{50}^{2}}\right)^{-0.344}$

Where $Q_{b f}$ is the bankfull discharge, $W_{b f}$ is the channel width at bankfull conditions, $S_{b f}$ is the channel slope at bankfull conditions and $D_{50}$ is the median grain size. Using these relationships, we calculated the Froude number for bankfull conditions at a range of discharges in an idealized gravel bed river, assuming a median grain size of $10 \mathrm{~cm}$ and two values of the Manning's roughness coefficient. The Froude number at equilibrium conditions using the relationships proposed by Parker et al., (2007) are subcritical, typically in the range 0.2-0.3, whatever the value of the bankfull discharge. This shows that in steady uniform flow conditions, single thread gravel bed rivers are not expected to be close to supercriticality, and would not do so even after significant narrowing due to the weak dependency of Fr on channel width (eq. S3). The Parker et al., (2007) relationships (equations S4, S5) are empirical based on a dataset of 72 gravel bed rivers in the UK, Canada, and the USA, which exhibit a degree of universality between them, but do not pertain to braided rivers which are very often the state of rivers during terrace aggradation phases (e.g., Hanson et al., 2006). Using high resolution lidar topography and the Floodos hydrodynamic model, we explored the characteristics of the flow conditions at bankfull conditions for a braided river, the Rakaia river in New Zealand. The present day conditions of the Rakaia are a good analogue both for the initial conditions of the experiments and for the former conditions of many present day rivers that are incised with flights of terraces abandoned on the valley sides (e.g., Charwell River, New Zealand; Bull, 1990).

The supercritical flow conditions that initiated the development of cyclic steps in the experiments (Fig. S9) occurred after channels had narrowed following the initial stripping of 
the sediment cover. Therefore, we performed some simple tests using the DEM of the Rakaia river to explore the impact of different constant channel widths with a fixed discharge on the Froude number (Fig. S9A), and the impact of different discharges in a constrained fixed width channel (Fig. S9B). For a fixed discharge, a narrower channel increases the average value of the Froude number and for a fixed width, increased discharge also increases the average values of the Froude number.
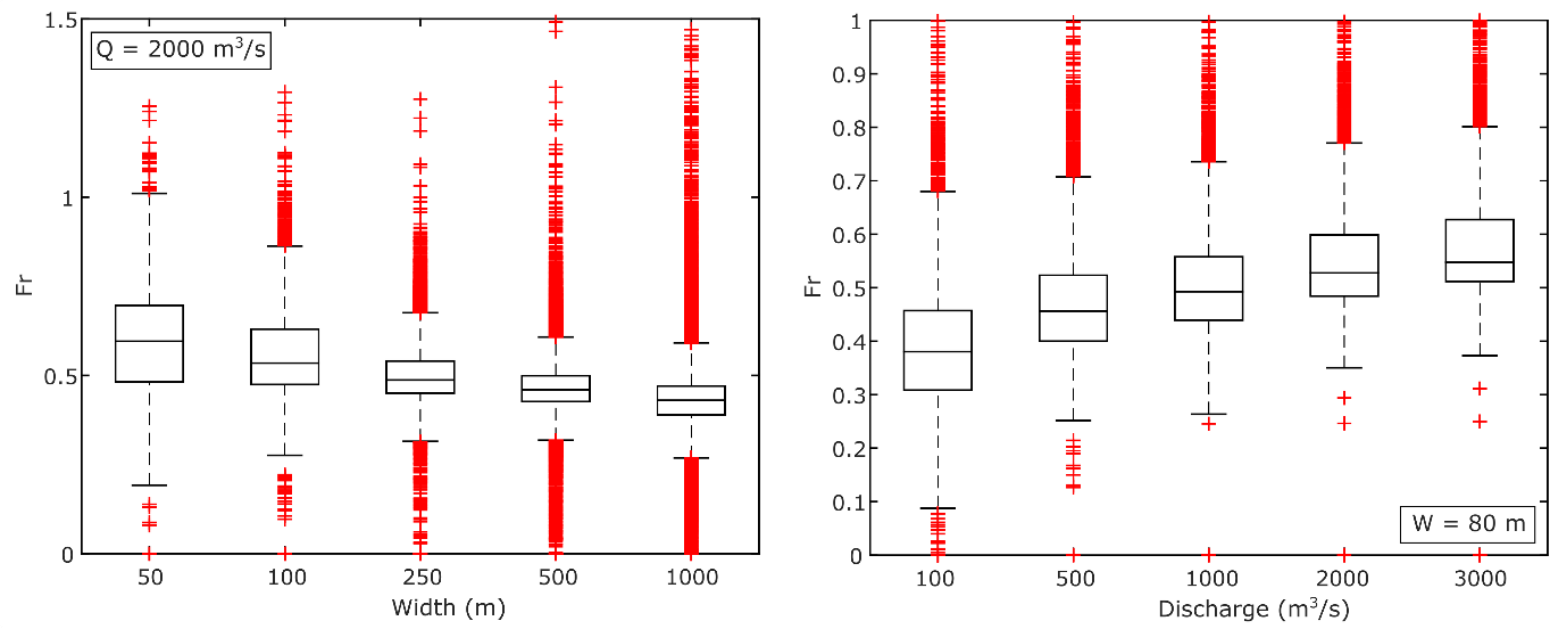

Fig. S9: (A) Impact of channel width on Froude number for a fixed discharge $\left(Q=2000 \mathrm{~m}^{3} \mathrm{~s}\right.$ $\left.{ }^{1}\right)$. (B) Impact of discharge on Froude number for a fixed width $(W=80 \mathrm{~m})$. As predicted by equation S3, both width and discharge have a small impact on the average Froude number in the channel, but the flow can become supercritical in a few locations.

The average values of the Froude number remain sub-critical for the scenarios presented in Fig. S9, but the peak values of Fr approach supercriticality due to the local spatial variations in the flow conditions. The numerical simulations in Fig. S11 were carried out using a straight channel, which is overly simplistic for a natural river system. The maps of Froude number for the Rakaia (Fig. S10B) river indicate that flow conditions are not spatially uniform at bankfull discharge and are subcritical $(\mathrm{Fr}<1)$ but the values of the Froude number can be higher ( 0.4-0.6) than the values predicted by the relationships of Parker et al., (2007). However, it is possible to have supercritical flow conditions during frequent floods when the flow is focussed into a narrower channel with a spatially non-uniform channel width (Fig. S10C-E). Such conditions may be present in natural settings following a perturbation to the sediment supply or transport capacity and the subsequent stripping of sediment cover and focussing of the flow into a significantly narrower channel with spatially variable width (Fig. 2A). The simulations in Fig. S10 were carried out with no alteration to the channel slope. If the slope of the bedrock surface is steeper than the slope of the alluvial channel flowing over the 
603

604

605

606

607

608

609
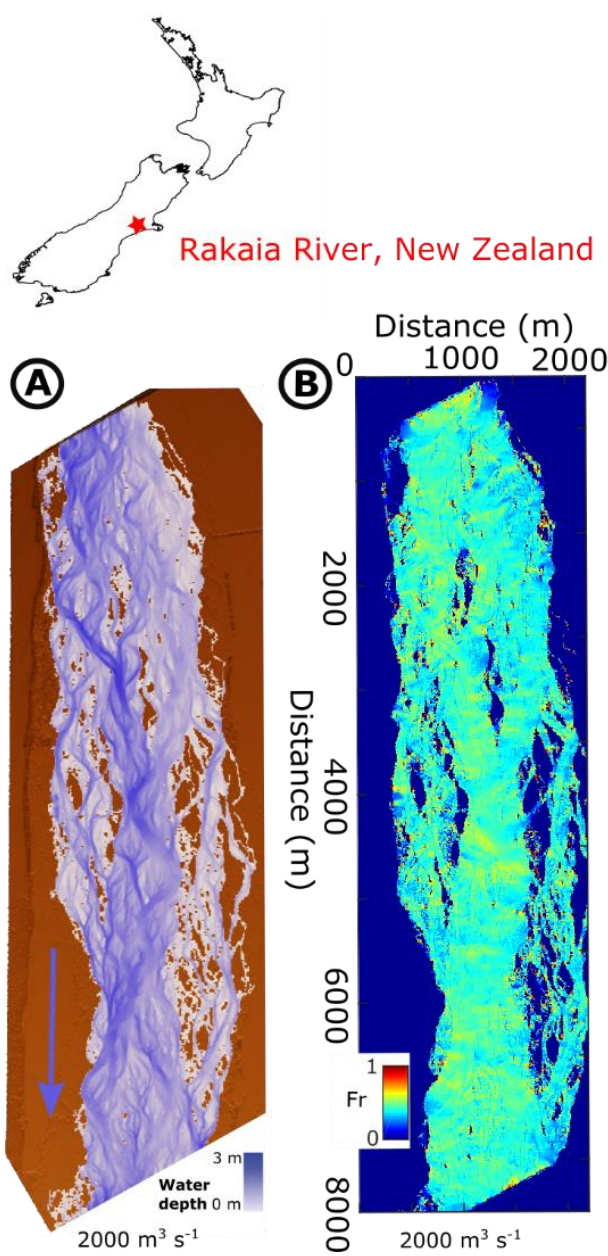

Distance $(\mathrm{m})$

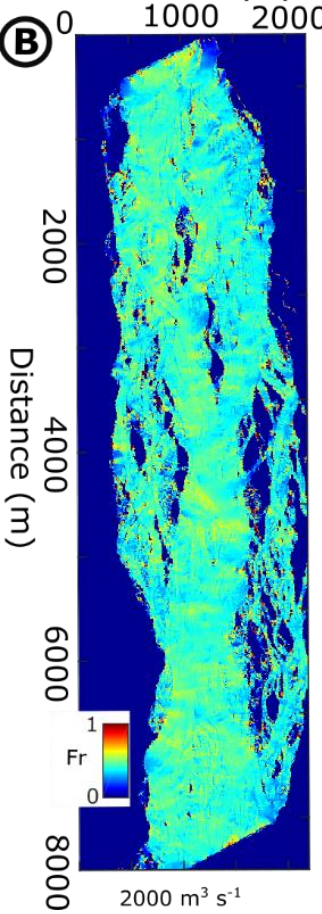

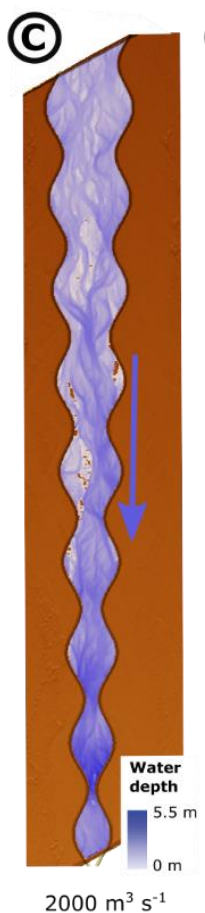

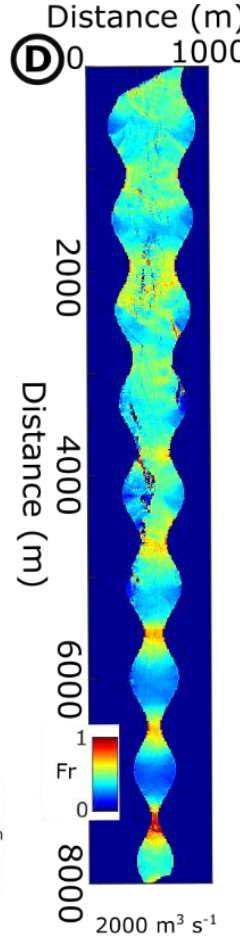

$2000 \mathrm{~m}^{3} \mathrm{~s}^{-1}$

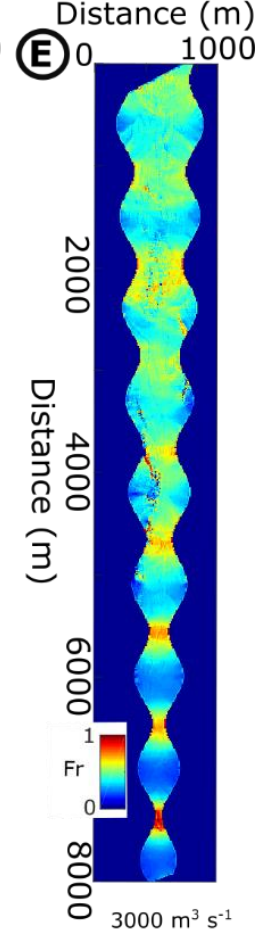

611

612

613

614

615

616

617

618

619

sedimentary deposits (e.g. Finnegan and Balco, 2013), the likelihood of supercritical flow and the possible development of bed instabilities that evolve into knickpoints is increased. We therefore suggest that the processes leading to rapid strath terrace generation through selfformed knickpoint retreat, in the absence of any vertical perturbation to the bed elevation, identified in the experiments are possible in natural environments.

Fig. S10. (A) Map of water depth for a reach of the Rakaia river, New Zealand, under bankfull conditions $\left(Q=2000 \mathrm{~m}^{3} \mathrm{~s}^{-1}\right)$, modelled using Floodos on a Lidar generated DEM (Released under Creative Commons By Creative Commons Attribution 3.0 New Zealand Link: http://data.linz.govt.nz/license/attribution-3-0-new-zealand/; downloaded from www.opentopography.org; DOI: 10.5069/G9JQ0XZV). (B) Map of Froude number, typically $\sim 0.4$, with some local areas slightly higher at $\sim 0.6$. Channel width variability and degree of channel constriction has impact on the water depth (C) and Froude number at $Q=2000 \mathrm{~m}^{3} \mathrm{~s}^{-}$ ${ }^{1}(D)$ and $Q=3000 \mathrm{~m}^{3} \mathrm{~s}^{-1}(\boldsymbol{E})$, with increasing degree of supercriticality with increased channel constriction and increased discharge. 


\section{SI References}

Baynes E.R.C., Lague D., Attal M., Gangloff A., Kirstein L.A., Dugmore A.J., 2018, River selforganisation inhibits discharge control on waterfall migration: Scientific Reports 8, 2444, https://doi:10.1038/s41598-018-20767-6

Davy P, Croissant T, Lague D (2017) A precipiton method to calculate river hydrodynamics, with applications to flood prediction, landscape evolution models and braiding instabilities. Journal of Geophysical Research. Earth Surface, v. 122, p. 1491-1512, https://doi.org/10.1002/2016JF004156

Finnegan N.J., Roe G., Montgomery D.R., Hallet B., 2005, Controls on the channel width of rivers: Implications for modelling fluvial incision of bedrock: Geology, v. 33 (3), p. 229232

Hanson PR, Mason JA, Goble RJ (2006) Fluvial terrace formation along Wyoming's Laramie Range as a response to increased late Pleistocene flood magnitudes. Geomorphology $76,12-25$

Hooke, R. 1968, Model Geology: Prototype and Laboratory Streams: Discussion: Geological Society of America Bulletin, v. 79, p. 391-94, https://doi.org/10.1130/00167606(1968)79[391:MGPALS]2.0.CO;2

Izumi N, Yokokawa M, Parker G (2017) Incisional cyclic steps of permanent form in mixed bedrock-alluvial rivers. Journal of Geophysical Research. Earth Surface, v. 122, p. 130152, https://doi.org/10.1002/2016JF003847.

Paola, C, K M Straub, D C Mohrig, and L Reinhardt. 2009. "The "unreasonable Effectiveness" of Stratigraphic and Geomorphic Experiments." Earth-Science Reviews v. 97, p. 1-43.

Parker G, Izumi N (2000) Purely erosional cyclic and solitary steps created by flow over a cohesive bed. Journal of Fluid Mechanics, v. 419, p. 203-238, https://doi.org/10.1017/S0022112000001403.

Parker G, Wilcock PR, Paola C, Dietrich WE, Pitlick J (2007) Physical basis for quasiuniversal relations describing bankfull hydraulic geometry of single-thread gravel bed rivers. Journal of Geophysical Research, v. 112, F04005. 